\title{
THE GREAT CHRONICLE OF THE CITY OF LONDON ${ }^{1}$
}

\author{
By Anna M. Campbell
}

When in London during the summer of $1938, M r$. Charles Brewer, of the faculty of the Rutgers Preparatory Scbool, visited the ancient Guildball. There be met Mr. F. L. Doutbwaite, the librarian, who told bim that The Great Chronicle of London was being printed entire for the first time from the unique manuscript in an edition exclusively for presentation. Mr. Brewer expressed the bope that a copy would be given to the Rutgers University Library. A few montbs later, when the book was completed, the copy arrived with the compliments of the Library Committee of the Guildball. It is described below by Dr. Anna M. Campbell, of the Department of History of the New Fersey College for Women, who several years ago was elected Fellow of the Royal Historical Society in recognition of ber distinguisbed study, The Black Death and Men of Learning.

$\mathbf{I}$ Is surprising that so important and interesting a document as The Great Cbronicle of London has existed till the present in a single manuscript copy which only passed into public ownership with its recent presentation by the Viscount Wakefield of Hythe to the Guildhall Library of London, where it is now Guildhall Library MS. 33 I3. The gratitude expressed by the Library Committee of the Corporation of the City of London in its dedication of The Great Cbronicle of London to the Right Honorable the Viscount Wakefield of Hythe will be felt by every user of this important and beautiful volume for whose appearance in print his generosity is responsible. Warm gratitude will also be extended to the editors, Mr. Thomas and $\mathrm{Mr}$. Thornley, for their fine work of transcription and editing.

The chronicle consists of two main parts: the first extends from II 89 to 1439 , and is written in a hand of the middle fifteenth century; the second, from 1439 to 15 I2, is in a handwriting of the late fifteenth or early sixteenth century. Each of the two parts falls in turn into two divisions, the first half of the first to 1399 , and of the second, to $1496 .{ }^{2} \mathrm{It}$ is written in

\footnotetext{
${ }^{1}$ Published at the Sign of the Dolphin, London, $193^{8}$ under the direction of the Library Committee of the Corporation of the City of London. This handsome edition of 500 copies was for presentation only; the copy presented to the Rutgers University Library is number 255.

${ }^{2}$ Great Chronicle, pp. xix-xx.
} 
English, and the editors have been careful in their transcription to reproduce the original as exactly as possible, even in punctuation and capitalization.

The Great Chronicle was actually written in the latter half of the fifteenth century, a period for which there is a relative scarcity of contemporary historical material, and is, therefore, especially valuable for the period from the middle of the fifteenth century to its conclusion in $\mathrm{I} 5 \mathrm{I} 2 .^{3}$ There are evidences of its having been used by John Foxe (1516-1 587) in his Actes and Monuments, and by John Stow (1 525-1604) in his Survey of London, his Summarie of Englysbe Cbronicles, and his Annales. In fact, there is reason to believe that the manuscript may have belonged for a time to each of these scholars. ${ }^{4} \mathrm{Mr}$. C. L. Kingsford, in his British Historical Literature of the Fifteenth Century, made a study of the manuscript in connection with contemporary London chronicles, and it was he who gave the work its title, remarking that "on account of its exceptional fulness [it] may be fitly described as The Great Cbronicle." He further calls it the "most ample representation of the English Chronicles of London in their earliest form."

For the period to I 399 the compiler of the first portion of the chronicle gathered his material from earlier writers, and shows marked resemblance to certain other chroniclers of his period. It may be assumed that there was a common archetype, perhaps a Latin original and one or more English versions used by the compilers of The Great Cbronicle and its fellows when dealing with the centuries preceding their own. For the period from I399-I439 there is less similarity among the fifteenth-century London chronicles, The Great Cbronicle resembling sometimes one and sometimes another document. ${ }^{6}$ It tends, however, to be somewhat fuller than the others, and becomes more so after 1439 . From this date till $\mathrm{I}_{4} 85$, the writer

${ }^{3}$ As to scarcity of material for this time see also Hunt, W., and Poole, R. L., editors, The Political History of England, Oman, C., vol. IV, 1377-I485, app. I, and Fisher, H. A. L., vol. V., I $485-1547$, app. I.

Oman remarks (p. 502): "So far as England can be said to have any contemporary historians at all between the death of Henry V and the outbreak of the Wars of the Roses, we must seek them in the persons who kept up the various London chronicles." Neither he nor Fisher appears to have made use of the manuscript copy of The Great Cbronicle.

${ }^{4}$ G. C., Pp. xvi-xvii, and xli-xliii.

${ }^{5}$ G. C., p. xxvi.

${ }^{6}$ For full discussion, see the introduction, and Kingsford, C. L., Brit. Hist. Lit. of the 15tb Cent. 
evidently used a rather detailed chronicle which was drawn on by several other chroniclers, but which is no longer in existence. He included additional material of his own, probably gathered from eye-witnesses, and after I485 he writes largely at first hand. This portion of the history is naturally of special value, and contains some matter not found elsewhere as far as the editors have been able to discover. The whole work, though especially the latter half, is marked, as its donor comments in his brief foreword, by "interest as a human document, revealing the author's character and at the same time affording a vivid and curious picture of London at the close of the Middle Ages."

The work is anonymous, but there are reasons for ascribing it to Robert Fabian, who was elected sheriff of London in I493, became alderman in I494, and twice served as Master of the Drapers' Company. The author's statement that he was apprenticed to Sir Thomas Cook of this guild reinforces one's belief that Fabian was the author of the latter part of The Great Chronicle.

Since the fifteenth century was a particularly picturesque and troubled period of English history, and since a historian active in London affairs wrote from a vantage point, a large part is played in these pages by kings and queens, princes, princesses, and nobles who shared in the glories and tragedies of their age. The author has taken pains to give at length documents bearing on the abdication of Richard II. He displays sympathy for Henry VI and his queen, and admiration for the ability of Henry VII. Parliament and the Commons figure frequently in his pages, valuable information is given about the affairs of the city of London, and economic matters and popular disturbances receive attention. The descriptions of pageants, jousts, feasts, and costumes are of value for the social history of the time.

Some of the material which apparently occurs only, or for the first time, in The Great Cbronicle possesses considerable interest. "A Balade of Empson," 7 is such a bitter attack on the former minister that the author follows it by "lett noo man that shall here or Rede this balad thynk, that ffor any malice or cawse of hurt $b^{t}$ the said Empson dyd unto the wryter of

'G. C., pp. 344-347. 
thys boke, that he hath newly Remembrid It." It was merely to point a lesson to those in high places. Others of these poems have to do with John Baptist de Grimaldis; there are three, of which the first is unusual in form, and the third and longest contains a stanza noteworthy as an early reference to marine insurance. ${ }^{8}$ It also contains a Chaucer allusion which does not seem to have been included in Miss Spurgeon's Five Hundred Years of Chaucer Criticism and Allusion. ${ }^{9}$

The Great Cbronicle is one of three sources which together give the complete Lollard petition of ${ }^{1} 4 \mathrm{IO}^{10}{ }^{10}$ Apparently nowhere else is found the sinister prophecy it quotes concerning little Edward V when, accompanied by the Duke of Gloucester, and just after he had been proclaimed king, he was received by the mayor and citizens of London:

Soo that upon the iiij day of maii the mayer and his brethys clad In Scarlet, and upon v C Comoners alle clothid In violet well horsid and well apparaylid, met wyth the kyng in harnesey park his Grace Rydyng In blew velvet, and the duke of Glowcetyr In course blak cloth, and alle the kyngys servauntys and hys were clothid alle In blak In soo much that than was myendid and spokyn of an old prophecy sayying, Whan the blak fllete of Norwaye, is cummyn and goon, Than buyld ye yowir howsis/Of lyme $\&$ of stoon.11

Another pathetic story about a child seems to be preserved only here. The account of the execution for treason of Tiptoft, earl of Worcester in 1470 is followed by instances of his cruelty:

${ }^{8}$ The poems occupy pp. $35^{2-365}$.

The stanza referred to, p. 360 , reads:

"What shuld I telle of thy ffals fforgyng

Of lettyrs of byllys, and sundry acquytauncis

What shuld I saye, of thyne Imagynyng

To stuff Shyppis, wyth ffals crafty balauncis

As bolkkys and stonys, and countyrfayt dalyauncis

And affyr assure, the said shippys $w^{t}$ theyr ffreygth

For grete Summys tyll they cam on the heygth."

${ }^{\circ}$ G. C., P. 361 :

$$
\begin{aligned}
& \text { "O most cursid Caytyff, what shuld I of the wryte } \\
& \text { Or tell the particulers, of thy cursid lyffe } \\
& \text { I trow if Skelton, or Cornysh wold endyte } \\
& \text { Or mastyr moor, they mygth not Inglysh Ryffe } \\
& \text { Nor yit Chawcers, If he were now In lyffe } \\
& \text { Cowde not In metyr, half thy shame spelle } \\
& \text { Nor yit thy ffalshod, half declare or tell" }
\end{aligned}
$$

${ }^{10}$ G. C., pp. xxvii, xxxi, 88-89, 408, 409-410.

11 G. C., p. 230. 
Thys man as above is said was ffamyd Crwell \& mercylees ffor soo much as he put to deth $i j$ sonys of therlys (the earl) of desmund which were soo tendyr of age, that oon of theym havyng a Byle or sore In his nekk said unto the execucioner whan he shuld smyte off/his hede, Gentyll Godffadyr beware of the sore In my nekk. ${ }^{12}$

The earliest reference to the city of London's crystal mace, borne by the mayor at coronations, occurs here in $1503 .{ }^{13}$ Several other passages dealing with mayors of the city may be quoted. One of I468, treats of the trial of the author's former master, Sir Thomas Cook:

To the which place the said sir Thomas was browgth \& there aregned upon lyffe $\&$ deth, In tyme whereof the mayer beyng a Replete and lumpysh man satt ffor chyeff Juge and slept, wherffor the duke syttyng upon his Rygth hand seeng his myssdemeanure said opynly In his derysion, sirs spekyth sofftly for the mayer is on slepe. ${ }^{14}$

Another item, of 1502, concerns Sir John Shaa, a mayor of different calibre:

Thys mayer alsoo browygth upp a newe besynesse whych beffore by any mayer, tyme of meynd was not occupyed, That is to meane that most what every afftir noune he held a court alloon and callid beffore hym many matiers and Redressid theym afftyr the Best of his myend, But not to all mannys pleasurs This man was of a sharp wytt and therwyth of a good $\&$ bold spyryt by Reson of the ffavour that he stood In wyth the kyng and Quene $\&$ many othir astatis of $\mathrm{p}^{\text {is }}$ land In soo much that he was sworn of the kyngys counsayll as the ffame went By auctoryte whereof he bare hym $\mathrm{j}^{\mathrm{e}}$ bolder and took upon hym thyngis that hath not soundid to his ffame syne his departyng, But who is In auctoryte that can please all parties, as whoo sayth noon, pan by Reson of these courtis kepyng which was of soom namyd the court of Requestis, moch of the pore people drew unto hym, whom he ffavourid more sometyme than Justyce and good lawe Requyrid, wherffore the men of mygth/murmured agayn hym \& said, that he that told the ffyrst tale had avauntage, ffor he was ffor the more party wyth hym best belevid, men of lawe also allowid not his doyng ffor they were hynderid by $I t$, ffor he endyd many maters which In the lawe wold have cost moche money, But not ffor that he contynuyed his tyme and soo dyd ij or iij mayris afftyr hym. ${ }^{15}$

A reputed champion of "the pore people" against whom "the men of mygth murmurid" of greater fame, or at least

12 G. C., p. 213 .

${ }^{13}$ G. C., p. 32I. "And next beffore the quenys Chare Rode the lordys except pe mayer which bare a mase of Crystall Garnysshid w' gold next unto the Chare."

${ }^{14}$ G. C., p. 206. The mayor was "Thomas Owlgrave Skynner," the Duke of Clarence.

${ }^{15} \mathrm{G} . \mathrm{C} .$, p. 320. 
notoriety, than Sir John Shaa was reported to be bestirring himself in the same year. This was Robin Hood, of whom our historian speaks in guarded terms:

This yere alsoo was quyk \& comon talking of a man which exercysid many pagentis afftir the comon ffame of the people, of Robyn hood, But among he Robbid and dyd sundry ffelonyes to the grete hurt of Sundry of the kyngis subgectis, The which soo contynuyng lastly abowth midsomyr he was takyn \& hys company Scalid, This was namyd Grenelieff, but what becam of hym the certaynte was not opynly knowyn, albe It that sundry talys were told of hym which as uncertayn I ovyr passe. ${ }^{16}$

"No contemporary source," say the editors, "presents so interesting and complete an account of the attack on the City by the Bastard of Fauconberg as does The Great Cbronicle." ${ }^{17}$ Though the date, I47I, takes us back in time, two passages from this narrative belong here as bearing upon the poor. The first is just after the landing of the Bastard in Kent:

Whereof the ffame being blowyn Into Essex, The ffaynt husbandys cast ffrom theym theyr sharp Sythys and armyd theym wuth theyr wyvis smokkis chese clothis and old shetis and wepenyd theym wyth hevy \& grete/Clubbys and long pycchfforkis and asshyn stavys, and soo In all haast sped theym toward london, makyng their avaunt as they went that they wold be Revengid upon the mayer ffor settyng of soo easy penyworthis of their Buttyr Chese Eggis piggis \& all other vytayll, and soo Joyned theym unto the kentysh men. ${ }^{18}$

And, after the insurrection was quelled: "Such as were Rych were hangid by the purs, and the othir that were needy were hangid by the nekkis." 19

Reference has already been made to the excellence of editing and printing and the handsome appearance of this work. The introduction and notes are full, and marked by critical research and scholarship. There are two indexes, one to the manuscript chronicle to I496, apparently contemporary with the writing of the chronicle, the other, most satisfactory to use, to the printed edition. There is also a glossary. In the transcription, the editors have given the marginal and interpolated notes of the manuscript as well as the folio numbers. There are included in the volume ten facsimile pages to illustrate points of interest about the manuscript.
${ }^{16}$ G. C., p. 319.
${ }^{17}$ G. C., p. lxxiv.
${ }^{18}$ G. C., p. 218.
${ }^{19}$ G. C., p. 22 I. 
\%/la the

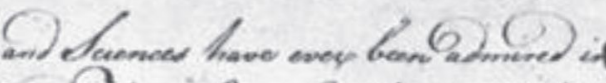

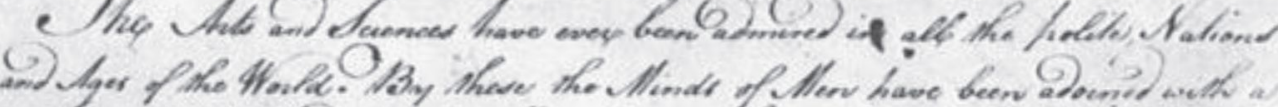

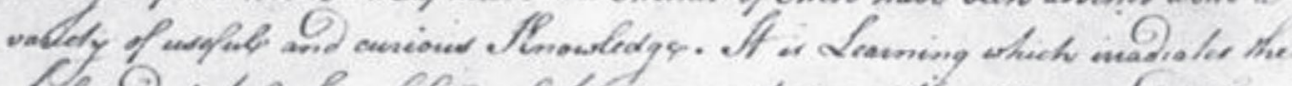

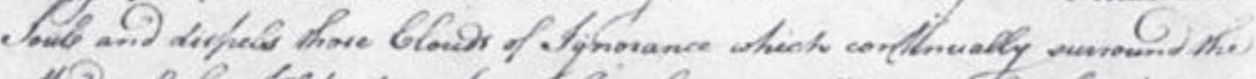

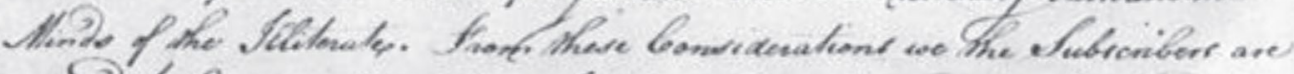

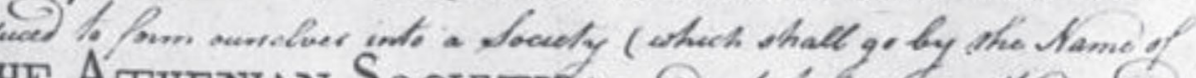

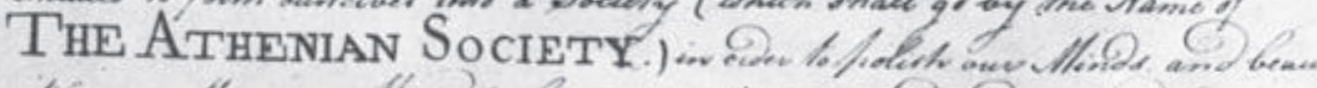

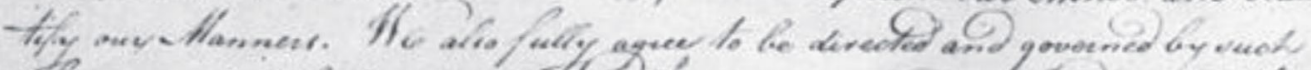

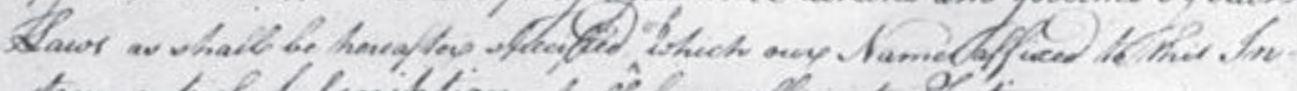

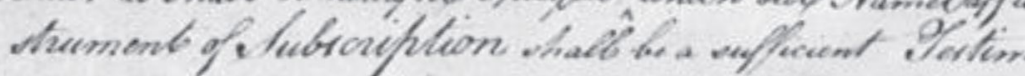

fohn Payloz

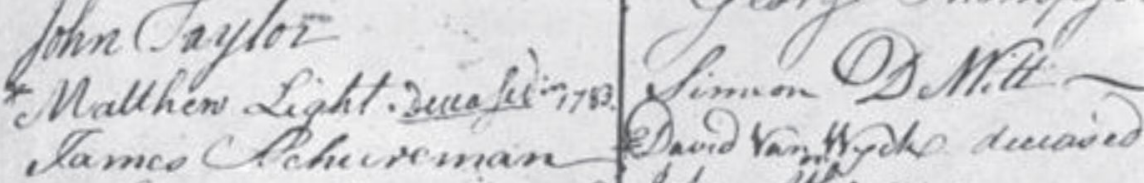

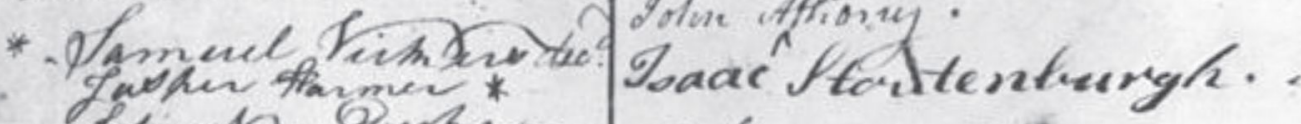
fohntangeythe. Davie Imman.

* Jompogento. Neverter

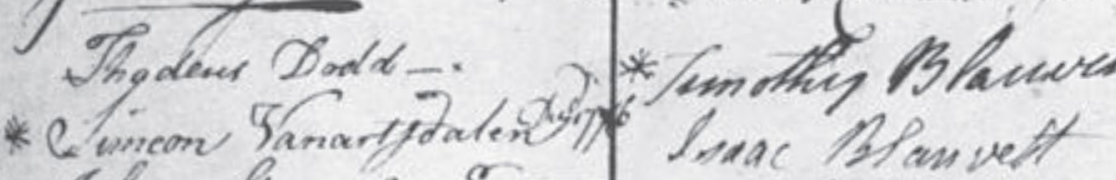
John Thes Ofulingingum. cieme ryortand Gohn ftagq jum irar Aricholag Alanoing fo heading Bsalfy

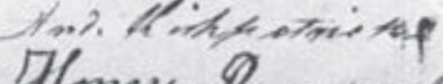
Dloney Memues,

Signatures of Members

From Transactions of The Atbenian Society 